This item was submitted to Loughborough's Research Repository by the author.

Items in Figshare are protected by copyright, with all rights reserved, unless otherwise indicated.

Teaching interpersonal skills: convincing the student of the need for an extreme opening statement in negotiations

PLEASE CITE THE PUBLISHED VERSION

PUBLISHER

(C) Taylor \& Francis

LICENCE

CC BY-NC-ND 4.0

REPOSITORY RECORD

Kniveton, Bromley H.. 2019. "Teaching Interpersonal Skills: Convincing the Student of the Need for an Extreme Opening Statement in Negotiations". figshare. https://hdl.handle.net/2134/2634. 
This item was submitted to Loughborough's Institutional Repository by the author and is made available under the following Creative Commons Licence conditions.

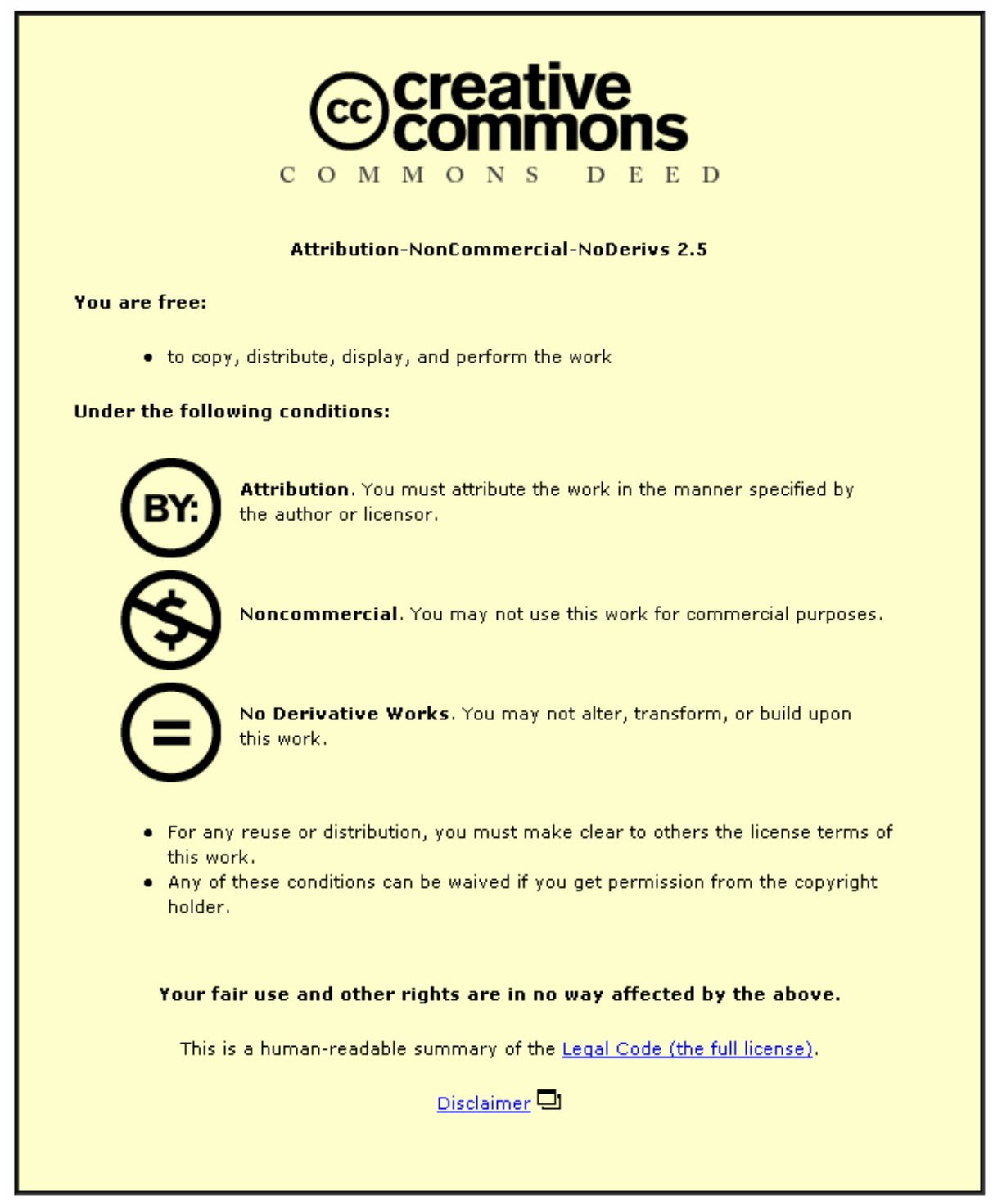

For the full text of this licence, please go to: http://creativecommons.org/licenses/by-nc-nd/2.5/ 


\title{
CLughborough
}

Journal of Vocational Education and Training 56. 3. P 435-448 2004

\section{TEACHING INTERPERSONAL SKILLS: CONVINCING THE STUDENT OF THE NEED FOR AN EXTREME OPENING STATEMENT IN NEGOTIATIONS}

\author{
BROMLEY H. KNIVETON \\ Department of Social Sciences, Loughborough University, Loughborough, Leicestershire. LE11 3TU
}

\begin{abstract}
Training young people in work related interpersonal skills can be difficult. For them adopting ritualistic tactics such as using an extreme opening statement in a negotiation is a very different approach to communicating than the cryptic and concise technique they use when, for example, they send a text message. This study assesses whether it is today an appropriate interpersonal skill. The study examined the impact of an extreme opening statement on young people acting as both management and union representatives. It was found both responded more generously when they received a more extreme opening statement than a more moderate one. This occurred no matter how reasonable the statement was seen to be. Males and females reacted similarly to an extreme statement. It was suggested it may today be considered a sound negotiating strategy. The case study itself can be used in vocational courses, which include interpersonal skill training components, as a means of demonstrating the effectiveness of the strategy.
\end{abstract}

\section{Introduction:}

Most occupations require some level of competence in the use of interpersonal skills. Being able to negotiate is one such skill, which has a widespread use when contact between individuals occurs. We tend to think of it in the very limited context of trade unions and car sales. Many vocational courses include some interpersonal skills training. For many trade apprentice programmes basic negotiating skills can form a useful part of these elements. It is something they will need to do when they have to negotiate the terms of a job, or contract, with clients. This will be particularly important for the self employed. Customer service personnel continually negotiate with their dissatisfied customers and every receptionist or personal assistant needs some interpersonal negotiating skills. More and more the general public, when dealing with those in business, question prices and terms. Courses for those providing many types of services need to include training in interpersonal skills. Training young people to negotiate is difficult because they have built up their own behaviours on the basis of their past experiences. These sort of behaviour patterns are always difficult to change. For example the student's experience of text messaging, with cryptic and concise communication, is totally different to what in the past has been a successful negotiating strategy. This has typically involved a ritualistic, extreme opening statement. When it is suggested to students they ask for more than they really want (their extreme demand point) as a ploy, and then settle for something less, (their moderate target point) the idea is frequently rejected in favour of an 'honest' approach where they simply state their moderate target point.

Trainers need to explain to the student that negotiating involves both a knowledge of the factual detail of the negotiation, and techniques of how to put these facts over in the most potent manner. Lewicki (1997), describes a negotiation as 'a complex skill set composed of a variety of component parts', one of which concerns this study. De Dreu (2003) for example, emphasises a negotiation is a social situation, characterised by an ongoing interaction. According to Shell (2001), courses need to cover a variety of negotiating styles to take in the characteristics of the individual student. This concept can create a great difficulty for some students. Negotiating styles tend to be based on past behaviour patterns, either at home of with friends. For example, Ishida (2003) notes how gender differences in negotiating in the home are very largely based on the resource base available to the male and the female. This highlights one of the many factors which can influence the style of the individual negotiator. An apprentice, for example, on a vocational course, will bring with them ideas and interpersonal skills based on their experience at home and school. 
DAlo (2003) argues that participants need to have a firm grasp of the procedure involved in a negotiation. From the researcher's experience, the idea that there are procedures which should be followed can be a difficult one for students to accept. Often students believe that an honest, straightforward approach is all that is required. They argue others will accept they are a person who means what they say because everyone does today. The old style techniques of negotiating can be seen as being outdated by the young college student. This view can be hard to shift. It is difficult to convince students that a technique used at a car boot sale (offering very little in the hopes of reaching an acceptable price) can be a valuable skill in the workplace. For the receptionist or personal assistant dealing with the public they need to appreciate ritualistic steps, like this, have a part to play in their interactions with their clients or customers. They give both sides an opportunity to discover what the other side has in mind, and thus plan their own strategy. The act of doing this provides each with the time and space to plan ways in which some sort of agreement acceptable to both sides, which has a lasting effect, can be reached. Failure to achieve this will make any future transaction between the pair far more difficult. A second difficulty, when trying to convince someone who has negotiating experience, of the value of starting with a extreme opening statement is that if they do not use it they find it hard to see whether they would have done better by using it. The consequences of the alternative behaviour cannot be seen. This does mean that the failure to use an extreme opening statement makes it unlikely they will ever try it.

Research into this strategy has a long history. Stevens (1963) argued that the initial demand should be large enough to permit what he terms 'room for bargaining', but not so large as to lose contact completely with the opponent's bargaining spectrum, which will increase the chance of confrontation. Sevinth (1967) noted early initiation of co-operative behaviour (a reasonable opening statement) tends to promote the development of trust and mutually beneficial, co-operative relationships. Early competitive behaviour (a very extreme opening statement), on the other hand, tends to induce mutual suspicion and competition. Hamner (1974) later found an extreme opening statement can make later concessions more likely. According to Rubin and Brown (1975) the opening stance indicates a competitive or co-operative attitude. Pruitt and Syna (1985) used the purchase/sale of a used car as a task to establish what factors determine whether a subject would establish this sort of room to manoeuvre. They found extreme initial statements produced concessions or lower opening bids from the other than would otherwise be the case. In a more recent study, Shapiro and Bies (1994) report that negotiators who use threats and bluffs were perceived as more powerful, and less co-operative, and achieved less integrative agreements than did those who did not use threats. In summary, it would seem, from these early studies, extreme initial positions can have a beneficial effect, assuming they are not too extreme, in which case they can be counter productive. Social behaviours are, however, constantly changing and interaction patterns appropriate thirty, or even ten years ago may not apply in the business world of today, where young people think and behave very differently to their predecessors. It is therefore constantly necessary to review strategies and behaviours, in the light of changing social expectations. This is the purpose of this study.

A further issue arises from the increase, during recent years, in the percentage of females in the workforce. There is evidence which suggests gender can be a variable influencing negotiating. According to Terhune (1968), women react more extremely than men if they feel the other side is being unreasonable, and according to Pruitt and Syna (1985) women engaged in more 'mismatching' than men being particularly likely to exploit a soft opponent. King and Hinson (1994) report that in single and mixed sex negotiating pairs, males got better deals than their female opponents when purchasing in mixed sex pairs, and male sellers generally outperformed female sellers. Carol Watson (1994) in a review of eight studies found that gender did not affect tactical behaviour, but it did affect confidence. She did find, however, that the gender of a negotiator's opponent affected negotiation behaviour, and that females were particularly sensitive to an opponent's gender. This is taken into account in the design of the present study.

In the present study, an industrial negotiation is used. The purchase/sale situation is not used in this study, as it is one of the few areas where it is often accepted that the demand/target scenario is seen as normal. For training purposes exercises are often more readily accepted by students if they are set in a new situation. The effect on both management who are receiving a claim, and union who are receiving an offer, is examined. Management and union can have very different experiences in a negotiation. Management can on occasions be in the position of negotiating in terms of 'giving' and the union in terms of 'asking' for items. The experience of the two parties can therefore be very different. This is on a similar basis to the advantage Olekalns and Frey (1994) noted was experienced by the purchaser, in a purchase/sale exchange. The present study examines the impact of an extreme opening negotiating stance by the 'other party', taking into account the perceived reasonableness of the initial statement presented.

It was hypothesised that: 
1. the reaction of management representatives to an extreme opening statement of claim would be more generous than to a less extreme statement.

2. the reaction of union representatives to an extreme opening statement of offer would be more generous than to a less extreme statement.

3. female participants would react in a more competitive manner than males when faced with an extreme opening statement.

\section{METHOD}

\section{Participants:}

A total of 208 second and third year undergraduates participated in the study (104 male and 104 female). Each took part individually and in each instance both males and females were allocated randomly, within numeric limits, to one of four experimental conditions. 52 male and 52 female participants were randomly allocated the management role and 52 of each sex the union role. Half the management representatives received from the union an extremely high and the other half a moderate claim. Half the union representatives received from the management an extremely low and the other half received a moderate offer. Details of the case study were varied according to whether the participants represented management or union. As can be seen in the appendix the negotiation was based on five separate issues included in a business case study, which together formed the content of the total negotiation.

\section{Procedure:}

The study was described to the participants as a decision making study, a neutral title to avoid specific expectations regarding its nature. It involves a variety of issues differing in significance to the negotiator who received information about their own and the other party's situation. This has the characteristics which Pruitt and Carnevale (1993) point out are typical of many negotiations having an offer and counter offer.

The participants were presented with a negotiating position in writing, supposedly devised by another party. To this they were expected to respond, by indicating on a series of scales what their final negotiating stand would be to the proposal. This task was used as it provided a means of taking into account the extremes of the initial position. It also provided a measure of how reasonable the initial statement was considered to be and took into account the gender of the 'other party'. The case study could be read and assimilated quickly. The whole exercise took about thirty minutes for each participant to complete. It can thus be usefully used in a training course as a means of demonstrating the strategy of using an extreme opening statement.

All participants were instructed to 'do their best' and achieve the 'best possible settlement'. No goals or targets were given. This avoided the problem created by specifying targets as Northcroft et al (1994) found, performance of negotiators was influenced by these, and Poizer and Neale (1995) reported that where goals were specified, negotiators tended not to incorporate new information received during negotiations. The total package of instructions was presented to the participants and they were asked to respond to the opening offer/claim contained in the written submission, which was supposedly from the other party in the negotiation. They were not told the gender of this supposed other party, as King and Hinson (1994) found gender mix had an effect on negotiating behaviour and it was intended here to control for this factor.

For management participants, the high claim was at the top of each scale, representing the most extreme stand that could be taken, and the low claim at the mid point of each scale. For the union participants, the extreme offer was set at the bottom point, the moderate at the mid point of the scale. It was considered that the position on the scale would make it clear to the other party how reasonable the statement was. The mid point is usually the point people select if they do not have strong feelings on an issue and therefore it was judged by the researcher to represent moderation. Five and nine point scales were used prevent the students simply opting to answer each item by selecting the same point on the scale for each item. This practice had the more important effect observed in a previous study, (Schwarz 1999), of making it possible to vary the extreme inferences of the scale. He found a pole position on a five point scale could appear to be less extreme than a similar position on a nine point scale.

The participants were asked to respond to each opening statement by deciding on the position on the scales they would consider acceptable. It was stressed that although they should make a decision on each of the five issues, they did form a total package and they should bear this in mind when reaching their decision. In addition, they were asked to rate the opening statement on each of the constituent items of the other party's claim/offer on a seven point scale from very reasonable (1) to totally excessive (7).

\section{RESULTS}


1. the reaction of management representatives to an extreme opening statement of claim would be more generous than to a less extreme statement.

The first hypothesis is largely supported, as can be seen in table I. With a high opening claim by the union, the female managers agree to a significantly higher settlement than when a low opening claim is submitted. With male managers their response is in the same direction, although not statistically significant.

Table I

Showing what management settled for after receiving the union claim.

\begin{tabular}{|c|c|c|c|}
\hline & $\begin{array}{l}\text { The mean total amount } \\
\text { in } £ \text { male management } \\
\text { settled for. Standard } \\
\text { deviation in brackets } \\
\mathrm{N}=26\end{array}$ & $\begin{array}{l}\text { The mean total amount } \\
\text { in } £ \text { female management } \\
\text { settled for. Standard } \\
\text { deviation in brackets } \\
\mathrm{N}=26\end{array}$ & $\begin{array}{l}\text { Difference between } \\
\text { male and female } \\
\text { managers } \\
\text { T score df. prob }\end{array}$ \\
\hline $\begin{array}{l}\text { Low claim from } \\
\text { union }\end{array}$ & $£ 11,576.92(£ 5,468.90)$ & $10,336.54(5,278.70)$ & $\begin{array}{lll}0.83 & 50 & .058\end{array}$ \\
\hline $\begin{array}{l}\text { High claim from } \\
\text { union }\end{array}$ & $\begin{array}{l}15,701.92 \\
(5,468.90)\end{array}$ & $\begin{array}{l}18,255.77 \\
(8,129.81)\end{array}$ & $\begin{array}{lll}\text { 1.03. } & 50 & .58\end{array}$ \\
\hline $\begin{array}{l}\text { Difference between } \\
\text { high and low claim }\end{array}$ & $\begin{array}{l}\mathrm{T}=1.90 \\
\mathrm{Df}=50 \\
\text { Prob= .06 }\end{array}$ & $\begin{array}{l}\mathrm{T}=4.16 \\
\mathrm{Df}=50 \\
\text { Prob=.0002* }\end{array}$ & \\
\hline
\end{tabular}

The participants in this study did see the extreme claims as less reasonable as is shown in table II. In spite of this the management gave more when they received a high claim which they considered less reasonable than when they received a low claim which they considered more reasonable. This shows the strategy is not affected by how reasonable it is seen to be.

Table II

Showing overall assessment of how reasonable the managers feel the union claim is.

High score indicates less reasonable.

\begin{tabular}{|l|l|l|l|}
\hline & $\begin{array}{l}\text { Male management } \\
\text { Mean score and std. In } \\
\text { brackets } \\
\mathrm{N}=26\end{array}$ & $\begin{array}{l}\text { Female management } \\
\text { mean score and std in } \\
\text { brackets } \\
\mathrm{N}=26\end{array}$ & $\begin{array}{l}\text { Difference between } \\
\text { male and female } \\
\text { managers } \\
\text { T score df. Prob }\end{array}$ \\
\hline $\begin{array}{l}\text { Low claim from } \\
\text { union }\end{array}$ & $3.88(1.03)$ & $1.7950 \quad .07$ \\
\hline $\begin{array}{l}\text { High claim from } \\
\text { union }\end{array}$ & $4.92(1.13)$ & $4.23(1.36)$ & $1.9950 .05^{*}$ \\
\hline $\begin{array}{l}\text { Difference between } \\
\text { high and low claim }\end{array}$ & $\begin{array}{l}\mathrm{T}=3.46 \\
\mathrm{Df}=50 \\
\text { Prob=.001* }\end{array}$ & $\begin{array}{l}\mathrm{T}=2.55 \\
\mathrm{Df}=50 \\
\text { Prob=.01* }\end{array}$ & \\
\hline
\end{tabular}

\section{2. the reaction of union representatives to an extreme opening statement of offer would be more} generous than to a less extreme statement.

The second hypothesis is also supported, as can be seen in table III when looking at the union reaction to an offer from management. Both male and female union representatives agree a lower settlement point when management make a low offer.

Table III

Showing what the union settled for after receiving the management offer.

\begin{tabular}{|c|c|c|c|}
\hline & $\begin{array}{l}\text { The mean total amount } \\
\text { in } £ \text { male union settled } \\
\text { for. Standard deviation } \\
\text { in brackets } \\
\mathrm{N}=26\end{array}$ & $\begin{array}{l}\text { The mean total amount } \\
\text { in } £ \text { female union settled } \\
\text { for. Standard deviation } \\
\text { in brackets } \\
\mathrm{N}=26\end{array}$ & $\begin{array}{l}\text { Difference between } \\
\text { male and female } \\
\text { union } \\
\text { T score df. prob }\end{array}$ \\
\hline $\begin{array}{l}\text { Low offer from } \\
\text { management }\end{array}$ & $\begin{array}{l}15,586.54 \\
(6.048 .53) \\
\end{array}$ & $\begin{array}{l}14,72.15 \\
(4,580.12)\end{array}$ & $\begin{array}{lll}0.49 & 50 & .10\end{array}$ \\
\hline $\begin{array}{l}\text { High offer from } \\
\text { management }\end{array}$ & $\begin{array}{l}21,596.15 \\
(7,840.94\end{array}$ & $\begin{array}{l}24,182.69 \\
(5,141.77)\end{array}$ & $\begin{array}{lll}0.52 & 50 & .61\end{array}$ \\
\hline Difference between & $\mathrm{T}=3.09$ & $\mathrm{~T}=7.01$ & \\
\hline
\end{tabular}




\begin{tabular}{|l|l|l|l|}
\hline high and low offer & $\begin{array}{l}\mathrm{Df}=50 \\
\text { Prob=.003* }\end{array}$ & $\begin{array}{l}\mathrm{Df}=50 \\
\text { Prob=.0000* }\end{array}$ & \\
\hline
\end{tabular}

The reasonableness scale shown in table IV indicates male union representatives regard the lower offer as less reasonable the higher offer but they still agree a lower settlement point. With female union representatives they do not view the lower offer as being any less reasonable than the higher one.

Table IV

Showing overall assessment of how reasonable the union feel the management offer.

High score indicates more reasonable

\begin{tabular}{|l|l|l|l|}
\hline & $\begin{array}{l}\text { Male union Mean score } \\
\text { and std. In brackets } \\
\mathrm{N}=26\end{array}$ & $\begin{array}{l}\text { Female union Mean } \\
\text { score and std. In brackets } \\
\mathrm{N}=26\end{array}$ & $\begin{array}{l}\text { Difference between } \\
\text { male and female } \\
\text { union } \\
\text { T score df. prob }\end{array}$ \\
\hline $\begin{array}{l}\text { Low offer from } \\
\text { management }\end{array}$ & $2.81(1.06)$ & $3.08(1.02)$ & $0.93 \quad 50.64$ \\
\hline $\begin{array}{l}\text { High offer from } \\
\text { management }\end{array}$ & $4.00(1.38)$ & $2.92(1.09)$ & $3.1150 .003^{*}$ \\
\hline $\begin{array}{l}\text { Difference between } \\
\text { high and low offer }\end{array}$ & $\begin{array}{l}\mathrm{T}=3.49 \\
\mathrm{Df}=50 \\
\text { Prob=.001* }\end{array}$ & $\begin{array}{l}\mathrm{T}=0.52 \\
\mathrm{Df}=50 \\
\text { Prob=.61 }\end{array}$ & \\
\hline
\end{tabular}

It would seem therefore that with both management and union representatives the tactic of using an extreme opening statement encourages the other side to move in the direction of being more generous with their responses.

\section{3. female participants would react in a more competitive manner than males when faced with an extreme opening statement.}

The third hypothesis is rejected. There is no significant gender difference between managers or union representatives regardless of whether they are subject to the moderate or extreme opening statement. Indeed, the female managers gave a more generous response to a high union claim than to a low one. This finding conflicts with those of Terhune's (1968) study, but this could perhaps, be explained in terms of changing social expectations of females over the period since that was carried out.

\section{DISCUSSION}

The first two hypotheses are supported as the results show that the higher the opening claim from the union, the higher the figure decided on by management in response. The union adopt a lower response figure when the management makes a lower offer. This finding, which was predicted on the basis of the literature over many years (e.g. Atkinson 1975, Pruitt and Syna 1985 and Druckman 1994), does emphasise the crucial importance of the opening statement to both sides. This shows that the traditional negotiating ploy of 'going in high', really does have an effect on the 'other side'. This finding is an important one in the context of social changes in behaviour and expectations. It is even more marked in that it was carried out with young people, who are probably good representatives of modern social mores and behaviours. Young students on vocational courses may be able better to relate to this study than to studies conducted in the workplace on older workers. It does show that interpersonal negotiation strategies which have been in use for many years, are still appropriate today.

This study does draw attention to a number of factors often neglected in the literature. First, that the effect works for both management and union negotiators. The figures for the overall claim, which have been described in the results section, are made up from a series of separate negotiating issues. The extreme case did not always produce a more generous response from the other side, but in the majority it did. Here lies a problem when trying to convince the student of the merits of the strategy. When something the trainer is trying to put over does not happen every time it can make it difficult to convince students it works. This is always a problem when teaching interpersonal skills. Certainly, however, with this study it is shown that the effect of offering low or claiming high is felt in the majority of instances.

In spite of this indication of what people actually do, they are fully aware when the other side submits an unreasonable extreme opening statement. Their view of the reasonableness of the other side does not, however, appear to moderate their actions. Even when management feels that the other side is submitting an unreasonably high claim, they still react more generously than when they receive a lower claim. With the union representatives, even though they consider a high offer from management as being reasonable, they still react by 
demanding more than when they are initially given a less generous offer. College students, from my experience, often assert that being reasonable will be appreciated. This study suggests this is not the case.

The results of this study fail to provide support for the presence of a gender difference in reactions to an extreme negotiating strategy. The finding that when females are presented with an extreme claim or low offer they react more excessively than males (Terhune 1968) and engage in more mismatching (Pruitt and Syna 1985) is not supported. The results shown here support Carol Watson's (1994) more recent views, arguing that there is little difference in the negotiation strategies of males and females.

This study has attempted to show whether the traditional strategy of making an extreme opening statement can affect the response. With a variety of very different issues, from both the management position of receiving a claim, and the union position receiving an offer, it would appear the opposing party tends to move in the direction of the extreme statement. This does not depend on the issue nor on the gender of the participant and appears to be unrelated to the perceived reasonableness of the opening statement. A caveat with regard to all interpersonal skills must be applied to this negotiating strategy. The study was conducted on young British students and it must be recognised there are major cultural differences in what are considered acceptable negotiation strategies. The tactic may not be appropriate in other cultural environments.

From the point of view of the trainer, this rather simple case study has demonstrated how a negotiating strategy has survived the test of time, and may still be appropriate today. It also provides a quick means of demonstrating the phenomena to doubting students. It is particularly interesting in that it shows that reasonableness in a negotiation appears to make no difference to the reaction of the other party. Other research findings, however, such as those of Druckman (1994) warning about the possible adverse effects of a very extreme opening statement should be heeded, to ensure a negative reaction is not evoked.

The case study used is a useful one for those running courses which incorporate training in interpersonal skills. It is not a complex study to administer, and does show a clear and robust effect of the impact of modest and extreme initial statements. The actual study requires little preparation and takes only about thirty minutes to administer in a class. It does provide a vehicle for the trainer to use to illustrate a point which students often find difficult to accept. The researcher has also used it many times in training courses as a case study in its own right as the basis for an actual interpersonal negotiation. It does not take long to brief the participants and provides much scope for ingenuity and the practice of negotiating tactics. Obviously the issues can be modified or simplified depending on the background and needs of the students.

\section{REFERENCES:}

Atkinson, G.G.H. (1975) The effective negotiator. Quest Research Publications. London.

DAlo, G.E. (2003) Justice understanding, and mediation: when talk works, should we ask for more? Negotiation Journal. 19. 3. 215-227.

De Dreu, C.K.W. (2002) Time pressure and closing the mind in negotiation. Organizational behaviour and human decision processes 91. 2. 280-295

Druckman, D. (1994) Determinants of compromising behaviour in negotiation: A meta-analysis. Journal of conflict resolution. 38.3.507-556.

Hamner, W.C. (1974) Effects of bargaining strategy and pressure to reach agreement in a stalemate negotiation. Journal of personality and social psychology. 30. 458-67.

Ishida, J. (2003) Rationality and society 15. 3. 361-380

King, W.C. and Hinson, T.D. (1994) The influence of sex and equity sensitivity on relationship preferences, assessment of opponent and outcomes in a negotiation experiment. Journal of management. 20.3.605-624.

Lewicki, R.J. (1997) Teaching negotiation and dispute resolution in colleges of business: The state of the practice. Negotiation Journal 133 253-270

Northcroft, G.B. Neale, M.A. and Earley, P.C. (1994) Joint effects of assigned goals and training on negotiator performance. Human performance. 7.4.257-272. 
Olekalns, M. and Frey B.F. (1994) Market forces, negotiator frames and transaction outcomes. European journal of social psychology. 24. 403-416.

Poizer, J.T. and Neale, M.A. (1995) Constraints of catalysts? re-examining goal setting with the context of negotiation. Human performance. 8.1.3-26.

Pruitt, D.G. and Syna, H. (1985) 'Mismatching the opponents' offers in negotiation. Journal of experimental social psychology. 21. 2. 103-113.

Pruitt, D.G. and Carnevale, P.J. (1993) Negotiation in social conflict. Open University Press: London

Rubin, J.Z. and Brown, N.B.R. (1975) The social psychology of bargaining and negotiation. Academic press. London.

Schwarz, N. (1999) Self reports: How the questions shape the answers. American Psychologist. 54.2. 93-105

Sevinth, R.L. (1967) The establishment of the trust relationship. Journal of conflict resolution. 11. 335-344.

Shapiro, D.L. and Bies, R.J. (1994) Threats, bluffs and disclaimers in negotiations. Organizational behaviour and human decision processes 60.1.14-35.

Shell, G.R. (2001) Bargaining styles and negotiation: The Thomas-Kilmann conflict mode instrument in negotiation training. Negotiation journal 17. 2. 155-174.

Stevens, G.M. (1963) Strategy and collective bargaining. McGraw-Hill. New York.

Terhune, K.W. (1968) Motives, situation, and interpersonal conflict within prisoner's dilemma. Journal of personality and social psychology. Monograph supplement. 8.3.2.

Watson, C. (1994) Gender versus power as a predictor of negotiation behaviour and outcomes. Negotiation journal. 10.2 117-127.

\section{Appendix \\ Background to the Case Study:}

All participants were informed that the company, Tripart Trolleys, had been established for twenty years, and manufactured small fibre glass battery driven vehicles used for warehouse stacking. The total workforce consisted of 150 men and women, involved in the manufacture of the fibreglass bodies, in assembling the metal chassis and in the electrical wiring of the vehicles. The current production rate is 300 vehicles per year. Each vehicle is currently selling at $£ 7,500$, which is in line with the three other manufacturers in this country. Tripart is operating at full capacity and has a six-month order book. Profits are not as high as in previous years, as the company has raised the sale price less than inflation for several years, in order to maintain a competitive position. The company is currently making profits of about $£ 100,000$ per year. It has been able to pay shareholders annually a dividend totalling $£ 30,000$ out of this profit, and has made purchases each year of new equipment out of the rest to update plant.

The former managing director of the company, who retired three months ago, valued the reputation of Tripart as a 'good place to work'. His successor is viewed with some suspicion by the workers, due mainly to his statements about changing some of the work practices, to achieve greater efficiency.

Unemployment in Townsford where the plant is located is about the national average, but there are few other opportunities for the employees whose skills tend to be fairly specialised in the fibreglass and electrical area.

It is currently time for the annual wage and conditions negotiations. This is usually a fairly civilised process. Both management and union are reluctant to cause hostilities or unpleasantness, which may have an impact on future negotiations. This year, as in the past, there are a number of issues, which are on the table, and although they are detailed separately, they do form a complete package and any agreement on one item should be made in the context of the whole deal. This is something to take into account, when reaching decisions. 
Participants are informed either as management representatives or as union representatives that they should respond to the offer/claim in terms of their final negotiating position.

\section{Instructions given to management:}

You are to try to achieve the best settlement for the company. Although the company has a good order book, it is in danger of losing several major customers if increased labour costs result in a significant price increase. It is essential that the contract be settled in this bargaining period so that the sale price of the Tripart Trolley can be agreed with purchasers in the near future. A lot therefore hangs on your next move. It is realised this may involve compromise on both sides and you are appointed to carry out binding negotiations. Your next move must be your final one. Remember that each week on strike could cost the company an estimated £34,000 in lost profits and unproductive running expenses, and overtime later to make up the shortfall in production. You will be expected to justify your decision to top management. You have received the following claim from the union.

\section{Instructions given to union:}

Union members were dissatisfied with the contract last year. There is a serious danger of divisions in the ranks of the union members if a more satisfactory contract is not achieved in these negotiations. It is essential to the workforce, however, that this contract is settled within the bargaining period. It is realised that this may involve compromise, but you are appointed to carry out binding negotiations. Remember your job is to reach a settlement that is good for the workforce in this negotiating period. Your next move must be your final one. Remember each week on strike could cost your workers an estimated $£ 34,000$ in lost wages. You will be expected to justify your decision at a meeting of the workers. You have received the following offer from management.

Details of the actual moderate and extreme initial statements are contained in the methodology section of this article.

Issues to be negotiated:

The five issues were presented to the participants in random order. In each instance the amount under the line on the scale is the total cost to the company or value to the total workforce of the scale point for 12 months.

\section{Compensation for cost of living increases rated on a five point scale.}

Past contract: Pay scale fixed through terms of contract

Quarterly adjustment for each per cent. of inflation at that time. Scale represents a proportion of each percent increase.

\begin{tabular}{lllllll} 
Company & 0 & $1 / 4$ & $2 / 4$ & $3 / 4$ & $4 / 4$ & union \\
\hline
\end{tabular}

\section{Cost/Value 12 months $£ 5,000$ for each point on the scale}

2. Wage rated on a nine point scale

Past contract: $£ 6.50$ per hour

Increase per hour

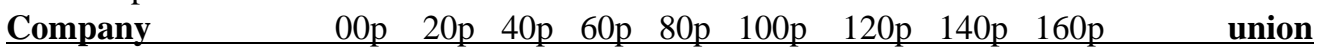

\section{Cost/Value 12 months $£ 2,000$ for each point on the scale}

3. Holiday pay rated on a five point scale

Past contract: 3 weeks in addition to statutory

Company No change extra 1 day 2 days 3days 4 days union

Cost/value $£ 500$ for each point on scale

4. Sick pay scheme rated on a five point scale

Past contract: Company pays 2/10 normal wages minus state benefit.

\begin{tabular}{llllll} 
Company no change & $4 / 10$ & $6 / 10$ & $8 / 10$ & $10 / 10$ & union \\
\hline
\end{tabular}

Cost/Value 12 months $£ 1,000$ for each point on the scale

5. Night shift differential rated on a nine point scale

Past contract: An extra 10p per hour is paid for night work

Company 0 5p 10p 15p 20p 25p $30 p$ 35p $40 p$ Union

Cost/value 12 months $£ 250$ for each point on scale 